\title{
SOCIALINĖS BRANDOS PSICHODIAGNOSTINIO VERTINIMO GALIMYBĖS TEISMO PSICHOLOGIJOS EKSPERTIZĖJE
}

\author{
Gintaras Butkus \\ Valstybine teismo psichiatrijos tarnyba prie Sveikatos apsaugos ministerijos
}

Raktažodžiai: socialinè branda, tapatumo būvis, lojalumas referentinei grupei, intelekto galios ir sunkumai.

\section{Santrauka}

Straipsnyje analizuojamas socialinès brandos paaiškinimo iš specialistų pusès teismams poreikis bei išskiriami tikètini socialinès brandos psichologiniai kriterijai ir jų vertinimo būdai. Teisinis socialinès brandos pagrindas išdèstytas LR BK 80-81 str. paskirtyje: užtikrinti, kad atsakomybė atitiktų šių asmenų amžių ir socialinę brandą; riboti laisvès atėmimo bausmès ir didinti auklejamojo poveikio priemonių taikymo asmenims iki $21 \mathrm{~m}$. amžiaus galimybes; padèti pakeisti gyvenimo būdą ir elgesį derinant baudimą už padarytą nusikalstamą veiką su jo asmenybès ugdymu, auklejjimu, neteisèto elgesio priežasčių šalinimu; sulaikyti nuo naujų nusikalstamų veikų padarymo. Lietuvos teismų praktikoje jaunų pilnamečių teisinè praktinè integracija ị nepilnamečių justicijos sistemą susiduria su dideliais sunkumais, iš kurių pirmiausia pažymètina socialinès brandos vertinimo kriterijų, metodikos bei specialistų, kurie padètų ịvertinti jauno pilnamečio socialinę brandą, deficitas. Psichologiniu požiūriu jauno pilnamečio socialine branda glaudžiai susijusi su suaugystės izžangos ir paauglystès raidos laikotarpių lyginamaja analize. Raidos psichologijoje sėkmingais paauglystès ịveikos kriterijais dažnai išskiriami apibrezžtas ir integruotas tapatumas, autonomiškumas ne tik nuo tèvų, bet ir bendraamžių grupinès įtakos, socialinių situacijų intelektinis supratingumas. Teismo psichologų ekspertų teismams teikiamos naudingos žinios, padedančios sprendžiant socialinès brandos klausimą, galètų būti susijusios su tapatumo būvio nustatymu ar tapatumo ypatumų aprašymu, tarpasmeninių santykių su tėvais ir bendraamžiais tyrinejimo išvadomis, intelekto galių ir sunkumų, ypač atkreipiant dèmesị ị tokius specifinius intelekto sudetinius komponentus kaip socialinis supratingumas ir kristalizuotas intelektas, psichodiagnostiniu įvertinimu.

\section{Ivadas}

Pagal LR BK 81 str. 2 d., kurios redakcija įsigaliojo nuo 2003-05-01, šio kodekso 90-94 str. nuostatos (bausmių ir jų skyrimo ypatumai nepilnamečiams, bausmès vykdymo atidejjimas nepilnamečiui, nepilnamečio atleidimas nuo baudžiamosios atsakomybès, lygtinis atleidimas nuo laisvès atėmimo bausmès prieš terminą arba laisvès atėmimo bausmès jam pakeitimas švelnesne bausme), taip pat 82 str. $1 \mathrm{~d} .1,2,3$ ir 5 punktuose numatytos auklejjamojo poveikio priemonès (ispèjimas, turtinès žalos atlyginimas arba jos pašalinimas, nemokami auklèjamojo pobūdžio darbai, elgesio apribojimas) gali būti taikomos asmeniui, kuriam nusikalstamos veikos padarymo metu buvo sueję aštuoniolika metu, tačiau nebuvo suejję dvidešimt vieneri metai, jeigu teismas, atsižvelgęs ị padarytos nusikalstamos veikos pobūdị, motyvus bei kitas bylos aplinkybes, o prireikus - i specialisto paaiškinimus ar išvadą, nusprendžia, kad toks asmuo pagal socialinę brandą prilygsta nepilnamečiui ir baudžiamosios atsakomybės ypatumų taikymas jam atitiktų šio kodekso 80 str. numatytą paskirtį (užtikrinti, kad atsakomybė atitiktų šiu asmenų amžių ir socialinę brandą; riboti laisvès atėmimo bausmès ir didinti auklëjamojo poveikio priemonių taikymo šiems asmenims galimybes; padèti pakeisti gyvenimo būdą ir elgesį derinant baudimą už padarytą nusikalstamą veiką su jo asmenybės ugdymu, auklejimu, neteisèto elgesio priežasčių šalinimu; sulaikyti nuo naujų nusikalstamų veikų padarymo). Ši redakcija ịsigaliojo po to, kai tais pačiais metais Europos Tarybos Ministrų komitetas rekomendacijoje Nr. R (2003) 20, išskirdamas užsitęsusio perejjimo ị pilnametystę aplinkybę, pabrèžè, jog valstybėms narèms svarbu numatyti galimybes, kad asmenims iki $21 \mathrm{~m}$., teisẻjui nusprendus, jog pagal brandą ir atsakingumą jie neprilygsta suaugusiems, būtų taikomos nepilnamečiams numatytos procesinès taisyklès bei intervencija (8). Būtent šioje redakcijoje išskiriamas konkretus amžiaus limitas bei teisiškai reikšminga kategorija 
- branda. Savo ruožtu ši rekomendacija nuosekliai iggyvendino tarptautiniuose teisès aktuose keltus jaunų pilnamečių baudžiamosios atsakomybès klausimus - Jungtinių Tautų standartinèse minimalios nepilnamečių teisenos igyvendinimo Pekino taisyklèse (1985-11-29), Europos Tarybos Ministrų komiteto rekomendacijoje Nr. R(87)20 dèl socialinès reakcijos į nepilnamečių nusikalstamumą (1987-09-17), Jungtinių Tautų nepilnamečių nusikalstamumo prevencijos Rijado gairèse (1990-12-14). Juose rekomenduojama šalių narių Vyriausybėms, esant reikalui, peržiūrèti įstatymus, susijusius su jauno amžiaus pilnamečiais teisès pažeidèjais, kad atitinkami teismai turètų galimybę priimti nuosprendžius, kurie savo prigimtimi yra auklejjamojo pobūdžio ir skatina socialinę integraciją, taip pat stengtis išplèsti nepilnamečiams itvirtintų principų taikymą ir jauniems pilnamečiams teisès pažeidèjams. Rijado gairèmis išsakyta principinè pozicija apie jaunimo nusikalstamo elgesio universalumą: ,jaunuolių elgesys, neatitinkantis visuotinių socialinių normų ir vertybių, dažnai yra sudedamoji brendimo ir augimo dalis ir daugelis žmonių jị savaime išauga“ (13). Tuo tarpu Pekino taisyklėmis apibrèžta baudžiamosios atsakomybès amžiaus ir vertinamų reiškinių nuostata: „tose teisinèse sistemose, kur pripažįstama nepilnamečių baudžiamosios atsakomybès amžiaus sąvoka, žemiausia šio amžiaus riba neturi būti nustatoma nuo pernelyg jauno amžiaus, atsižvelgiant ị emocinę, protinę ir intelektinę jaunuolio brandą" (14). Tarptautiniuose teisès aktuose netiesiogiai pripažistami tam tikri teoriniaimetodiniai jaunų pilnamečių socialinès brandos vertinimo sunkumai, todèl rekomenduojama skatinti ir remti lyginamuosius nepilnamečių nusikalstamumo ir jauno amžiaus pilnamečių asmenų nusikalstamumo ypatybių bei šioms amžiaus grupèms tinkamų perauklèjimo ir socialinès integracijos priemonių tyrimus. LR baudžiamojo kodekso komentaro, kuris kaip tik skirtas pateikti mokslinę teorinę kiekvieno Kodekso straipsnio analizę, jame vartojamų teisès terminų ar tam tikrų žodžių tikrosios prasmès ir reikšmès aiškinimą, I dalyje (2004) socialinès brandos kategorija paminèta kelis kartus: a) aprašant, kad kitos bylos aplinkybès - nusikalstamos veikos dalykas, jos padarymo būdas, ịrankiai, priemonès, laikas, vieta, tikslas ir pan. - turi rodyti nepakankamą socialinę aštuoniolikos-dvidešimties metų asmens brandą; b) apibrèžiant, kad socialinè branda - fizinio ir psichinio asmenybès brandumo pakopa, kurią skirtingi asmenys pasiekia skirtingo amžiaus; c) konstatuojant, kad vykdyti socialines savo kaip suaugusiojo pareigas ir priprasti prie tokio socialinio vaidmens, reikia nemažai laiko; d) išskiriant socialiai nebrandžių asmenų nusikalstamų veikmų priežastis - dažnai glūdinčias vaikysteje, tokie asmenys dažnai būna priklausomi nuo savo tèvų, gyvena kartu su jais, nėra sukūrę savo šeimų, tebesimoko, dar nedirba, laisvalaikị leidžia su vaikystės draugais, tad jų nusikalstamos veikos dažnai būna vaikiškos, neapgalvotos, padarytos kartu su nepilnamečiais bendrininkais; e) aprašant nepilnamečių socialinę brandą, ji atskleidžiama turimų žinių kiekiu, požiūriu ị aplinką ir supančius asmenis, gebejjimu vertinti visuomenès keliamus reikalavimus atitinkamo amžiaus žmonèms ir savo vietos supančioje aplinkoje žinojimu, gebejimu numatyti savo veikos padarinius ir juos planuoti, kritikuoti ir būti savikritiškam, atkakliu užsibrèžtu tikslų siekiu, galejjimu kontroliuoti savo emocijas ir veiksmus kritinèse situacijose bei kt.; f) nepilnamečių socialinę brandą siejant su emocine branda bei tam tikrais intelektinių gebejjimų lūkesčiais, tačiau visumoje išlaikant valinio komponento prioritetą - socialinių ir emocinių ,elementų nevisavertiškumas dẻl nepakankamo asmens išsivystymo lygio paprastai deformuoja ir valinị subjekto momentą“ (6). Tokiu būdu teisiškai vertinant socialinès brandos lygi pagrindiniu nagrinèjimo objektu turètų būti ne tiek pati nusikalstama veika, kiek jaunatviškas, paaugliškas mąstymo būdas, veikimo priežastys, elgesys prieš nusikalstamos veikos padarymą bei po jo ir kt. Tokiam aplinkybių turiniui nustatyti svarbu, jog visapusiška informacija apie aplinkybes, kurias vertindamas teisejjas turètų nuspręsti, ar asmuo pagal socialinę brandą prilygsta nepilnamečiui, būtų surenkama ikiteisminio tyrimo metu ir teisejjas, spręsdamas ši klausimą, disponuotų pakankamomis žiniomis apie jaunuolio gyvenimo būdą, nusikalstamos veikos padarymo aplinkybes, jo paties požiūrị ị savo veiką. ES šalių, tokių kaip Vokietija, ilgalaike ir nuosekli patirtis ne tik praktiškai igyvendinant tarptautinių teisės rekomendacinių normų, liečiančių jaunų suaugusių baudžiamosios atsakomybès teiseną, bet ir inicijuojama tų normų perspektyvinè plètra (pavyzdžiui, galimybè taikyti baudžiamosios atsakomybės ypatumus dar platesniam ratui asmenu -21-24 m. jauniems suaugusiems), tuo pačiu nubrěžia ir naują teisinio socialinès brandos vertinimo perspektyvą, kai nomotetinị požiūrị keičia ideografinis: Vokietijos Aukščiausiasis Federalinis Teismas išaiškino, jog jaunas pilnametis pagal brandą prilygintinas nepilnamečiui, jei „elementai rodo, jog ženklus asmenybès vystymasis dar laukia ateityje“, t. y. teismas remiasi ne įsivaizduojamu nepilnamečiu (jo prototipu), bet kaskart vertina kiekvieno asmens brandą ir vystymosi ypatumus (8).

Straipsnio probleminis klausimas - kokias naudingas žinias galètų suteikti teismo psichologai ekspertai teismams, sprendžiantiems jaunų suaugusių asmenų socialinès brandos klausimą?

Tyrimo tikslas: išanalizuoti socialinès brandos paaiškinimo iš specialistų pusès teismamas poreikị bei išskirti tikètinus socialinès brandos psichologinius kriterijus ir jų vertinimo būdus. 


\section{Tyrimo medžiaga ir metodas}

Tyrimo tikslu išanalizuota teisinè ir psichologinè su socialine branda susijusi literatūra, atlikta lyginamoji raidos psichologijos analizè socialinès brandos vertinimo aspektu.

Teisès instituto atliktas tyrimas nustate, kad nuo 200501-01 iki 2009-12-31 BK 81 str. 2 d. nuostatu taikymo klausimas Lietuvoje išnagrinètose bylose buvo iškeltas tik 36 atvejais (statistiškai po 7,2 karto per metus), iš jų tik 8 bylose šios nuostatos buvo taikytos. Be to, buvo nustatyta, kad tik du kartus tarp tirtų atvejų nuostatų taikymo klausimą teismas iškèlè savo iniciatyva, visais kitais atvejais socialinès brandos klausimą kèlè gynybos pusè, pateikdama surinktus duomenis. Iš jų 11 kasaciniame skunde, ir nei vienu atveju LR Aukščiausiasis Teismas BK 81 str. 2 d. nepritaikè (9). 2013 m. atliktas kitas kokybinio pobūdžio teismų praktikos tyrimas, kurio metu išanalizuota 23 ịvairių institucijų LR teismų sprendimų, priimtų 2006-2012 metais, kuriuose buvo keliamas BK 81 straipsnio 2 dalies nuostatu taikymas. 21 atveju klausimą inicijavo gynyba, 2 - teismas savo iniciatyva (5). Taip pat nustatyta, kad daugeliu atveju duomenis, daugumą kurių sudare medicininiai dokumentai, asmenị charakterizuojanti medžiaga, o žymiai rečiau - privačių ekspertų ar asmenų, turinčių specialiąsias žinias, pateiktas konsultacines išvadas, - savo iniciatyva rinko pats kaltinamasis ir/ar jo gynejas, kuris visais atvejais prašè skirti teismo psichiatrijospsichologijos ekspertizę, bet toks prašymas buvo patenkintas tik 3 bylose, o kitose 2 buvo nutarta teismo posédyje apklausti specialistus - psichologus ir/ar psichiatrus. Kitais atvejais tokie gynybos prašymai buvo atmesti, iš esmès nepateikiant jokių svarių motyvų. Be to, kaltinimo pusė nei vienoje byloje nepalaike gynybos prašymo, net ir tais atvejais, kai teismo nuosprendžiu buvo taikytos BK 81 str. $2 \mathrm{~d}$. nuostatos. Tokiu būdu keltina prielaida, kad teismai ir prokurorai BK 81 str. 2 d. nuostatos taikymą sieja išimtinai su baudžiamosios atsakomybès švelninimu, todẻl prašymus ją taikyti vertina itin skeptiškai, ignoruojant bet kokią galimybę nepakankamai socialiai brandžiam jaunuoliui užtikrinti papildomas jo procesinių teisių ir teisètų interesų apsaugos garantijas (5). Tuo tarpu Vokietijoje, kurioje po $1953 \mathrm{~m}$. reformos visi jauni pilnamečiai, padarę nusikalstamą veiką, stoja prieš jaunimo teismą, ir nuo $1990 \mathrm{~m}$. net 64 proc. visų jaunų pilnamečių, pažeidusių baudžiamają teisę, buvo teisiami pagal Jaunimo teismo ịstatymą, atitinkanti LR BK 81 str. 2 d. nuostatas, ir tai aiškiai parodo, kad jaunų pilnamečiu integracija ị nepilnamečių justicijos sistemą buvo sèkmingai pritaikyta praktikoje (8). Didžiojoje Britanijoje, neturinčioje atskiros jaunimo teismų praktikos, sulaikius jauną asmenį, dèl kurio pilnametystès kyla bent menkiausios abejonès, nedelsiant užtikrinama galimybè naudotis visomis nepilnamečiams skirtomis papildomomis procesinèmis garantijomis
(8). Atsižvelgiant ị šiuos faktus, esminis klausimas - kodèl Lietuvoje akivaizdžiai stringa jaunų pilnamečių teisinė praktinè integracija ị nepilnamečiu justicijos sistemą? Atliktas teisèjų nuomonès tyrimas $(2007 \mathrm{~m}$.) atskleidžia palankias jų nuostatas BK 81 str. 2 d. atžvilgiu (4). Siekiant išsiaiškinti problemas, su kuriomis susiduria teisejjai, taikydami BK normas ir skirdami bausmes konkrečiose bylose, buvo parengta speciali teisèjų ekspertinès apklausos anketa. Joje be bendrujų klausimų apie BK nustatytų sankcijų atitikimą nusikalstamų veikų pavojingumui, teisejjų buvo prašoma nurodyti ir konkrečius BK bendrosios ir specialiosios dalies straipsnius arba atskiras jų nuostatas, trukdančias individualizuoti bausmes, taip pat pateikti pasiūlymų dèl jų tobulinimo. Kai kurie teisejjai pažymėjo, jog susiduria su nemažomis problemomis ir neaiškumais praktiškai taikydami minètas BK straipsnių nuostatas, susijusias su nepilnamečių ir kitų asmenų nuo 18 iki $20 \mathrm{~m}$. amžiaus socialinès brandos ìvertinimu, kadangi ịstatyme nekonkretizuojama, kaip ji suprantama, nèra įteisintos metodikos ją nustatyti, taip pat nèra specialistų, kurie padètų ịvertinti jauno pilnamečio socialinę brandą, todèl dažniausiai atsisakoma tai daryti. Kaip išeitị iš susidariusios nuostatų taikymo aklavietès teiséjai rekomendavo „dažninti“, esant pagrindui, aptariamas įstatymo nuostatas, ir tokiu būdu kaupti atitinkamą metodinę patirtį. Nepaisant įstatymo leidejo suteiktos teismui teisès savarankiškai spręsti jauno pilnamečio socialinès brandos klausimą, teisès specialistai tuo pačiu pripažista, kad jaunuolių, padariusių nusikalstamą veiką, socialinès brandos samprata, jos turinio nustatymas nera tik teisinis klausimas, jis susijęs su psichologijos, pedagogikos, sociologijos ir kriminologijos mokslais, t. y. gali būti tarpdisciplininiu lygmeniu (8). Kita vertus, teisinèje mokslinèje literatūroje pabrèžiama, kad teismo psichologijoje nèra nei teorinio, nei metodinio pagrindo nustatyti asmens socialinę brandą, nèra suformuluotų socialinès brandos vertinimo kriterijų, todèl net teismui pasitelkus ekspertus, nèra aišku, ką jie turi ištirti ir nustatyti (8). Socialinès brandos sąvokos nėra psichologijos žodyne, taip pat ši sąvoka ar kita panaši savo turiniu neaprašyta jokiuose lietuvių kalba moksliniuose straipsniuose. Apibrèžtos tik iš dalies susijusios sąvokos - socialumas, socialinis atsilikimas, socialinis protas, sociopatinè asmenybè, subrendimas, branda, emocinè branda, infantilizmas, įtaigumas (2). Kita vertus, specialioje mokslinèje literatūroje skirtoje jauno pilnamečio brandos klausimams lygiaigrečiai naudojamos įvairios kategorijos - psichologinè branda, moralinè branda, psichosocialinė branda (9). Teismui sprendžiant BK 82 str. 1 d. nuostatų pritaikymą, svarbus ne tiek socialinès brandos turinio nustatymas, kiek jauno suaugusiojo individualių ypatumų prilyginimas nepilnamečiui, t. y. keliamas klausimas, kiek jaunas suaugusysis išlieka 
nesubrendęs raidos psichologijos požiūriu, kokie saviti psichologiniai požymiai gali paliudyti, kad jaunas suaugusysis vis dar išlieka paauglystès psichosocialiniame amžiuje. Klasikine asmenybės raidos teorija psichologijoje laikytinas E. Eriksono (1964) aštuonių psichosocialinès raidos pakopų modelis, kuriame paauglystès psichosocialinè krizè apibūdinta dviem alternatyvomis - tapatybė arba vaidmenų sumaištis (7). Paauglystės laikotarpiu išmokstama patirti vidini vientisumą, suvokiant ryši tarp savęs praeityje ir dabartyje bei ateityje, kokiu siekiama būti, todèl kartu ugdomas ir asmenybès kryptingumas (a). Kita paauglystės užduotis suvokti kitų lūkesčių savo atžvilgiu ir savo paties pasirinkimų sąsajas ir skirtumus, iš to formuojasi autonomiškumo savivoka (b). Dar viena užduotis - skirtingų vaidmenų skirtinguose kontekstuose laipsniška integracija, kurios pagrindu formuojasi vertybių hierarchija (c). Tokiu būdu paauglystès sèkmingą "posūkį" i jaunystès amžių atskleidžia išsiugdytas aiškus, apibrezžtas ir integruotas savasties jausmas - tapatybé; o nesėkmingą - intymumo vengimas, baiminantis netekti savęs, vaidmenų painiava. J. Marcia (7) praplètè E. Eriksono tapatumo krizès modelio empirinio pritaikymo galimybes, ivesdamas du kintamuosius, kurie nustatomi per maždaug pusvalandį trunkantị pusiau struktūruotą interviu. Pirmasis kriterijus - krizè - susijęs su aktyviu paauglio alternatyvų tyrinèjimu, kurios gali būti dichotomiškai apibréžiamos kaip jausmų sumaištis, nerimas, nepasitenkinimas arba priešingai - aktyvios pastangos išspręsti vidinị konfliktą, siekinat vientisumo jausmo. Antrasis kriterijus - įsipareigojimas - dichotomiškai vertinamas kaip nesavarankiškas arba savarankiškas sprendimų prièmimas. Kriterijų kombinacijos pagrindu galimi keturi skirtingi tapatumo būviai: neaiškus tapatumas, nesavarankiškas tapatumas, tapatumo moratoriumas ir pasiektas tapatumas. Tapatumo būviai, gali būti vertinami ir kaip skirtingos raidos pakopos, nes pirmasis iš esmès reiškia nebrandžiausią būvị, o paskutinis - brandžiausią. A. S. Watermano (11) teigimu, prasidedant paauglystei individas išgyvena arba neaiškaus arba nesavarankiško tapatumo būvị, ir tik apie 17-18-uosius metus prasideda sparčios permainos. Tokiu būdu jei pereinamuoju ị suaugystę laikotarpiu išlieka dominuojančiais mažiau brandūs tapatumo būviai - neaiškus tapatumas ar nesavarankiškas tapatumas - tikètina, kad toks tapatumas gali būti pripažintinas vienu svarbiu elementu rodančiu, jog "ženklus asmenybės vystymasis dar laukia ateityje". Vèlesni tapatumo tyrèjai tapatumo būvius pradèjo vertinti pagal skirtingas paauglių interesų sritis, pažymėdami, kad pastarosiose gali būti visiškai skirtingi to paties paauglio tapatumo būviai (10). Būtent tuo pagrindu L. Bennionas ir G. Adamsas (1) sukūrè ego tapatumo būsenų vertinimų metodiką, kuria atskirai vertinamos J. Marcia aprašytos būklès pagal ideologijos (religiniai įsitikinimai, politinès pažiūros, profesijos pasirinkimas, gyvenimo stilius) ir tarpasmeninių santykių (draugyste, partnerio paieškos, lyčių vaidmenys, laisvalaikio leidimas) sritis. Lietuvoje EOMEIS-2 klausimynas adaptuotas A. Vaičiulienès iniciatyva $2000 \mathrm{~m}$. VPU Psichologijos katedros bazejje, ir 2000-11-10 pseddyje rekomenduota kaip metodinè priemoné skirta psichologams (10). Tokiu būdu jauno suaugusio asmens tapatumo būvio, ypač tarpasmeninių santykių srityje, nustatymas moksliškai pripažistama metodika galètų būti vienu iš "specialistų paaiškinimų", kurie teismui būtų naudingi, sprendžiant socialinès brandos klausimą. Tarpasmeninių santykių sritį išskiriame dèlto, kad socialinèje psichologijoje gerai žinomas paaugliams būdingas lojalumo referentinei grupei fenomenas. Būtent grupè, su kuria paauglys tapatinasi, įtakoja jo vertybes bei elgesio motyvaciją, tuo tarpu buvusi psichologinè priklausomybė nuo tėvų, kitų anksčiau reikšmingų suaugusių autoritetų silpsta (emancipacijos fenomenas). LR baudžiamojo kodekso komentare buvo paminèta, kad socialiai nebrandžių asmenų nusikalstamos veikos dažnai būna vaikiškos, neapgalvotos, padarytos kartu su nepilnamečiais bendrininkais, jie gyvena su tèvais, yra jų išlaikomi, o laisvalaikị leidžia su vaikystės draugais. Šiame kontekste specialistas - teismo psichologas - teismui gali suteikti naudingų žinių ne tik apie tapatumo ypatumus, bet ir jauno suaugusio referentinès grupės ypatumus, jo vaidmeni šioje grupeje, santykị ị tokią grupę, ir kaip ịvykdyta nusikalstama veika susijusi su referentine grupe. Tokių sudètingų duomenų gavimas įmanomas tik profesionalaus pusiau struktūruoto interviu dèka, gauti duomenys turètų būti analizuojami trianguliacijos principu, remiantis duomenimis baudžiamojoje byloje surinktais duomenimis tiek apie pačią veiką, tiek iš asmeni charakterizuojančios medžiagos, derinat nustatytus tapatumo būvius su jauno suaugusiojo asmenybès emancipacijos/konformiškumo klausimais: realistinis gyvenimo planavimas ar gyvenimas šia diena (išsiaiškinami specialybès, šeimos sukūrimo, įsidarbinimo planai, atsakomybès suvokimas, iniciatyvos demonstravimas); savarankiškumas nuo tèvų ar atramos poreikis, bejègiškumas (išsiaiškinami santykiai su tèvais, materialinis ir psichologinis savarankiškumas, kiek ir kaip svarbi tėvų nuomonè ir valia); savarankiškumas nuo draugų ar lojalumas grupei (išsiaiškinama, koks santykis su draugu ar draugu grupe, ar grupemis, jų puoselèjamos vertybès, įtaka); atsakingumas ar legvabūdiškumas požiūryje į darbą, mokslus (išsiaiškinama pareiga ir atsakomybe išsilavinimui, darbinei veiklai, profesinès karjeros siekiamybei, savirealizacijai); demonstratyvus ar saikingas savęs išorinis pateikimas (išsiaiškinama, kiek išlieka paaugliškas noras atkreipti ị save demesį ryškiomis spalvomis, aksesuarais, atributais, aprangos stiliumi, šukuosenomis ir kt.); realistiškas kasdienybės išnaudojimas ar narcizišku- 
mas, išsiaiškinamas asmens kasdienis užimtumas - naudingos veiklos, hedonizmas, savo vertės pojūtis; santykių patvarumas ar trumpalaikiškumas; seksualinių troškimų integruotumas ị bendrą santykių kontekstą ar paaugliškas egoizmas; emocijų refleksija ar paaugliška nuotaikų kaita be refleksijos. Šalia jauno suaugusiojo tapatumo, tarpasmeninių santykių su tėvais ir bendraamžiais tyrinejjimo, dar vienos specialisto psichologo teikiamos teismui naudingos žinios, sprendžiant socialinès brandos klausimą, gali būti intelekto galių ir sunkumų aprašymas. Paradoksalu, kad standartizuota lietuviška suaugusiujų intelekto įvertinimo ir tyrimo metodika WAIS-III(LT) klinikinių psichologų dažniausiai naudojama siaurame protinio atsilikimo diagnozès pagrindimo kontekste. Tuo tarpu atsižvelgiant ị Pekino taisyklèse išsakytą poziciją dèl būtinybès įvertinti jaunuolių protinę ir intelektinę brandą, LR baudžiamojo kodekso komentare paminètą nuostatą, kad socialinè branda atskleidžiama ir per asmens gebejimą numatyti savo veikos padarinius ir juos planuoti, t. y. per "paauglišką" mąstymo būdą, svarbiau už IQ, bendro, verbalinio, neverbalinio, koeficientų, indeksų nustatymą tampa tokių intelekto sunkumų atskleidimas, kurie gali paliudyti apie jauno suaugusiojo socialinio mąstymo trūkumus, socialinių situacijų supratimo nebrandumą, kai bendras intelekto IQ išlieka normos ribose. VU Specialiosios psichologijos laboratorijos paruoštuose metodikos technikos vadovo priemonèse išskiriamas toks specifinis gebejimas kaip socialinis supratingumas, kurio nustatymas galios/sunkumo kontekste grindžiamas supratingumo ir paveikslèlių išdèstymo subtestų rezultatais, lyginant jų nuokrypi nuo subtestų bendro vidurkio. Sudètingesniu konstruktu, savotiškai pratęsiančiu ir praplečiančiu siauresnès reikšmès socialinị supratingumą, galima laikyti kristalizuotą intelektą, kuris vertinamas prie minėtų dviejų subtestų rezultatų, ịtraukus dar trijų subtestų duomenis: informacijos, panašumų ir žodyno. Kristalizuotas intelektas, dažnai vadinamas tvirtuoju, susijęs su gyvenimo eigoje kaupiamais igūdžiais bei žiniomis, kurios panaudojamos sprendžiant problemas, vaizdžiai palyginamas su "programine įranga", naudojančia kultūrinès aplinkos resursus (3). Tuo tarpu priešingas kristalizuotam - takusis arba fluidinis intelektas, kuris labiau susijęs su ịgimtais gebejjimais galvoti mąstyti, t. y. fundamentaliais sugebejimais apdoroti informaciją ir spręsti problemas. Toks intelektas, kad ir veikimas patirties, išlaiko smegenų veiklos apriori, jis tarsi smegenų mechaninè ịranga (3). Abiejų intelektų tyrimai atskleidžia, kad su amžiumi lankstusis intelektas tolydžiai pradeda silpnèti - maždaug apie 30 gyvenimo metus; tuo tarpu kristalizuoto įverčiai su amžiumi didejja, kol gilioje senatvejje padeda silpnèti (3). Tokiu būdu keltina prielaida, kad jaunų suagusiujų, kurie išlaiko "paauglišką" mąstymo būdą, kristalizuotas intelektas vertintinas kaip kliniškai reikšmingas sunkumas lyginant su kitais intelekto komponentais. Jaunų suaugusiujų tapatumo, tarpasmeninių santykių, socialinio supratingumo, kristalizuoto intelekto ypatumų sankloda gali būti svarbi ir kitu ekspertinio darbo aspektu: kai svarstomas lengvą protinị atsilikimą turinčių asmenų riboto pakaltinamumo klausimą. Pagal dabar galiojančias metodines teimo psichiatarijos rekomendacijas asmenys turintys lengvą protini atsilikimą iš esmès patenka ị galinčių suprasti savo veiksmų esmę ir juos valdyti kategoriją, su kai kuriomis išlygomis pripažistant, kad su lengvu protiniu atsilikimu asmenys, jei jie pasižymi tam tikromis asmenybės savybemis (ịtaigumas, infantiliškumas), atsižvelgiant ị nusikalstamos veikos aplinkybes, kuriose tokių savybių įtaka reikšminga, gali ir ne visiškai suprasti savo veiksmų esmę ir juos valdyti. Kita vertus, tokiu savybių objektyvaus įvertinimo galimybès gana ribotos, todèl išvada, kuri būtų grindžiama tapatumo, grupinio poveikio normomis, ịvertinus kliniškai reikšmingus gilesnius intelekto komponentų tokių kaip, socialinis supratingumas, kristalizuotas intelektas, sunkumus nei aprašoma lengvo protinio atsilikimo simptomatikoje, būtų labiau korektiška ir patikima.

\section{Išvados}

1. Tarptautiniuose teisès aktuose, susijusiuose su jaunų pilnamečių ir nepilnamečių baudžiamosios atsakomybès klausimais, priimta principiné nuostata, kad jaunuolių elgesys, neatitinkantis visuotinių socialinių normų ir vertybių, dažnai yra sudedamoji brendimo ir augimo dalis ir daugelis žmoniu jị savaime išauga, todèl rekomenduojama riboti laisvès atemimo bausmes ir didinti auklejamojo poveikio priemonių taikymo šiems asmenims galimybes, suteikiant galimybes pakeisti gyvenimo būdą ir sulaikyti nuo naujų nusikalstamų veikų padarymo.

2. Lietuvos teismų praktikoje jaunų pilnamečių teisinè praktinè integracija į nepilnamečių justicijos sistemą susiduria su dideliais sunkumais, iš kurių, pirmiausia pažymètina socialinès brandos vertinimo kriterijų, metodikos bei specialistų, kurie padètų įvertinti jauno pilnamečio socialinę brandą, deficitas.

3. Psichologiniu požiūriu jauno pilnamečio socialinė branda glaudžiai susijusi su suaugystės įžangos ir paauglystès raidos laikotarpių lyginamaja analize. Raidos psichologijoje sẻkmingais paauglytės įveikos kriterijais dažnai išskiriami apibrèžtas ir integruotas tapatumas, autonomiškumas ne tik nuo tėvų, bet ir bendraamžių grupinès ịtakos, socialinių situacijų intelektinis supratingumas.

4. Teismo psichologų ekspertų teismams teikiamos naudingos žinios, padedančios sprendžiant socialinès brandos klausimą, galètų būti susijusios su tapatumo būvio nustatymu 
ar tapatumo ypatumų aprašymu, tarpasmeninių santykių su tèvais ir bendraamžiais tyrinèjimo išvadomis, intelekto galių ir sunkumų, ypač atkreipiant dèmesị i tokius specifinius intelekto sudètinius komponentus kaip socialinis supratingumas ir kristalizuotas intelektas, psichodiagnostiniu įvertinimu.

5. Psichologinio socialinès brandos aspekto tyrimas turètų būti prilygintas sudètingai teismo psichologijos ekspertizei, atliekamai kaip aprašomosios tyrimo strategijos atvejo analizès porūšiui, naudojant kiekybinio ir kokybinio tyrimo metodus.

\section{Literatūra}

1. Bennion LD, Adams GR. A revision of the extended version of the objective measure of ego-identity status: an identity instrument for use with late adolescents. Journal of Adolescent Research 1986; 1:183-198. https://doi.org/10.1177/074355488612005

2. Bagdonas A., Rimkutė E. Anglų-lietuvių kalbų psichologijos žodynas. VU leidykla, 2013.

3. Baltes PB. Lifespan development and the brain. Cambridge, UK. Cambridge University Press, 2006. https://doi.org/10.1017/CBO9780511499722

4. Dapšys A., Misiūnas J., Čaplinskas A. Bausmès individualizavimo teisinès problemos. Teisès instituto mokslo tyrimai. Vilnius. Teisès institutas, 2008; 5: 35-37.

5. Gaidelytė D. Probleminiai nekaltumo prezumpcijos aspektai, įrodinejjant jauno pilnamečio nepakankamą socialinę brandą. Socialinių mokslų studijos, 2013; 5(3): 945-969. https://doi.org/10.13165/SMS-13-5-3-156.

6. LR baudžiamojo kodekso komentaras I dalis. Vilnius. Vilniaus spauda, 2004.

7. Marcia JE. The ego identity status approach to ego identity. In Marcia JE, Waterman AS, Matteson DR, Archer SL, Orlofsky JL (Eds.), Ego Identity: A Handbook for Psychosocial Research. New York. Spring Verlag 1993.

8. Prapiestis J. LR baudžiamojo kodekso komentaras, bendroji dalis. Vilnius. Registrų centras, 2004.

9. Ūselè L. Socialinès brandos sampratos ir turinio problema sprendžiant jaunų pilnamečių (18-20 metų) baudžiamosios atsakomybès klausimą. Vilnius. Teisès institutas, 2011; 78: 182-195.

10. Ūselè L., Dobrynina M. Nepilnamečių baudžiamosios atsakomybės ypatumų taikymo 18-20 metų jaunuoliams Lietuvoje tyrimas. Vilnius. Teisès institutas, 2012.

11. Vaičiulienè A. Asmenybès tapatumo ịvertinimas. Vilnius. VPU, 2001.

12. Waterman AS. Developmental perspectives on identity formation: from adolescence to adulthood. In Marcia JE, Waterman AS, Matteson DR, Archer SL, Orlofsky JL (Eds.), Ego identity: A Handbook for Psychosocial Research. New York. Spring Verlag 1993.
13. United Nations Guidelines for the Prevention of Juvenile Deliquency (Riyadh Guidelines). Adopted and proclaimed by General Assembly resolution 45/112 of 14 December 1990.

https://www.crin.org/en/docs/resources/publications/hrbap/ IHCRC/UnitedNationsGuidelinesforthePreventionofJuvenileDelinquency.pdf (2017-09-04)

14. United Nations Standard Minimum Rules for the Administration of Juvenile justice ("The Beijing Rules"). Adopted by General Assembly resolution 40/33 of 29 November 1985. http://www. ohchr.org/Documents/ProfessionalInterest/beijingrules.pdf (2017-09-04)

\section{THE POSSIBILITIES FOR A PSYCHODIAGNOSTIC ASSESSMENT OF SOCIAL MATURITY IN THE PSYCHOLOGICAL FORENSIC EXPERTISE}

\section{G. Butkus}

Key words: social maturity, identity status, loyalty for the reference group, intellectual capacity and difficulties.

Summary

The goal of this presentation is to analyse the importance of an expert input on social maturity for the courts and to identify the criteria for social maturity with the methods of their evaluation. The legal background of social maturity laid down in article 80-81 of the Lithuanian Republic Criminal Code: to make sure that a criminal liability corresponds with the age and social maturity of individuals under $21 \mathrm{y}$. o. to increase the practice of corrective measures which contribute to a personality development and a positive change in lifestyle and behaviour, to prevent further delinquency. The practical integration of young adults into the juvenile justice system in the Lithuanian judicial practice faces serious difficulties due to the lack of criteria for assessing social maturity, methodology and experts who could determine the social maturity of a young adult. From the psychological point of view, the social maturity of young adults is closely connected with a comparative analysis between the development of adolescence and the beginning of adulthood. Criteria for a successful transition identified by the developmental psychology are: defined and integrated identity, autonomy and independence from the influence of both parents and peer groups, intellectual understanding of social situations. The relevant knowledge given by the forensic psychologists to judges when deciding issues of social maturity could be related to a determination of identity status, description of identity peculiarities, analysis of interpersonal relationships with parents and peers, intellectual capacity and its difficulties when paying a particular attention to specific components of intelligence like the social understanding and crystallised intelligence.

Correspondence to: ginbut@gmail.com

Gauta 2017-09-29 